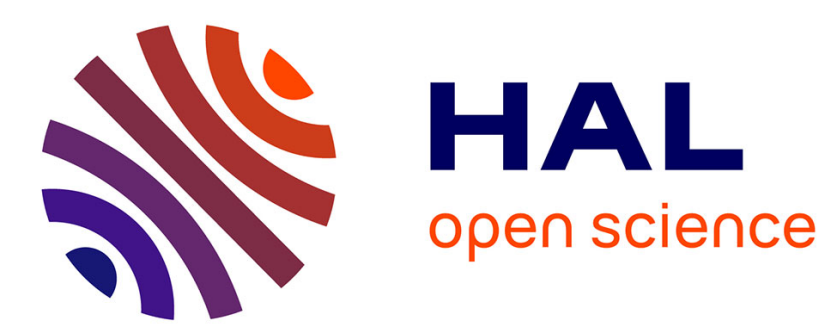

\title{
Eocene global warming events driven by ventilation of oceanic dissolved organic carbon
}

\author{
Philip Sexton, Richard D. Norris, Paul A. Wilson, Heiko Pälike, Thomas \\ Westerhold, Ursula Röhl, Clara T. Bolton, Samantha Gibbs
}

\section{- To cite this version:}

Philip Sexton, Richard D. Norris, Paul A. Wilson, Heiko Pälike, Thomas Westerhold, et al.. Eocene global warming events driven by ventilation of oceanic dissolved organic carbon. Nature, 2011, 471 (7338), pp.349 - 352. 10.1038/nature09826 . hal-01668002

\section{HAL Id: hal-01668002 \\ https://hal.science/hal-01668002}

Submitted on 19 Oct 2021

HAL is a multi-disciplinary open access archive for the deposit and dissemination of scientific research documents, whether they are published or not. The documents may come from teaching and research institutions in France or abroad, or from public or private research centers.
L'archive ouverte pluridisciplinaire HAL, est destinée au dépôt et à la diffusion de documents scientifiques de niveau recherche, publiés ou non, émanant des établissements d'enseignement et de recherche français ou étrangers, des laboratoires publics ou privés. 


\section{Multiple Eocene 'hyperthermal' events driven by ocean}

\section{ventilation}

Philip F. Sexton ${ }^{1,2^{*}}$, Richard D. Norris ${ }^{1}$, Paul A. Wilson ${ }^{2}$ Heiko Pälike ${ }^{2}$, Thomas Westerhold ${ }^{3}$, Ursula Röhl ${ }^{3}$, Clara T. Bolton ${ }^{2} \&$ Samantha Gibbs $^{2}$

${ }^{1}$ Scripps Institution of Oceanography, University of California, San Diego, La Jolla, CA 92093, USA.

${ }^{2}$ National Oceanography Centre, University of Southampton, European Way, Southampton, SO14 3ZH, UK.

${ }^{3}$ MARUM - Center for Marine Environmental Sciences, University of Bremen, Leobener Strasse, 28359 Bremen, Germany.

"Present address: Department of Earth and Environmental Sciences, Open University, Milton Keynes, MK7 6AA, UK.

'Hyperthermals' are intervals of rapid, pronounced global warming known from six episodes within the Palaeocene and Eocene Epochs ( $\sim 65$ to 34 million years (Myr) ago) ${ }^{1-13}$ - the most extreme of which was the $\sim 170$ thousand year $(\mathrm{kyr})$ interval $^{2}$ of 5 to $7^{\circ} \mathrm{C}$ global warming ${ }^{3}$ during the Palaeocene-Eocene Thermal Maximum (PETM, $55 \mathrm{Ma})$. The PETM is widely attributed to massive release of greenhouse gases from buried sedimentary carbon reservoirs ${ }^{1,3,6,11,14-17}$ and other, comparatively modest hyperthermals have also been linked to the release of sedimentary carbon ${ }^{3,6,11,16,17}$. Here we show, using new 2.4 million year-long Eocene deep ocean records, that the comparatively modest hyperthermals are much more numerous than previously documented, paced by orbital eccentricity and have shorter durations ( $40 \mathrm{kyr})$ and more rapid recovery phases than the PETM. These findings point to the operation of fundamentally different forcing and feedback mechanisms than for the PETM, involving redistribution of carbon among Earth's readily exchangeable surface 
reservoirs rather than carbon exhumation from, and subsequent burial back into, the sedimentary reservoir. Specifically, we interpret our records to indicate repeated, large-scale releases of dissolved organic carbon (at least 1600 gigatonnes) from the ocean by ventilation. The rapid recovery of the carbon cycle following each Eocene hyperthermal strongly suggests that carbon was re-sequestered by the ocean, rather than the much slower process of silicate rock weathering proposed for the $\operatorname{PETM}^{1,3}$. Our findings suggest that these pronounced climatic warming events were driven not by repeated releases of carbon from buried sedimentary sources $^{3,6,11,16,17}$, but, rather, by patterns of surficial carbon redistribution familiar from younger intervals of Earth history.

Earth's climate attained its warmest state of the past 80 million years (Myr) during the early Palaeogene Period ( $\sim 5$ to 65 million years ago [Ma]) (Fig. 1a). Centered within this interval at $55 \mathrm{Ma}$, the Palaeocene-Eocene Thermal Maximum (PETM) marks a rapid 2.5 to $>3.0 \%$ excursion in the carbon isotope composition $\left(\delta^{13} \mathrm{C}\right)$ of marine carbonates $^{1,3}$ and terrestrial organic matter concurrent with widespread dissolution of carbonate sediments ${ }^{1,3}$ and deep ocean warming by 6 to $7{ }^{\circ} \mathrm{C}^{3}$. The source of carbon triggering this large perturbation to the exchangeable carbon reservoirs at Earth's surface (ocean, atmosphere and biosphere) is widely acknowledged to have come from an 'external' sedimentary reservoir(s) $)^{1,3,6,11,14-17}$. A long-standing hypothesis attributes this event to the release of massive amounts of methane from sedimentary gas hydrate deposits ${ }^{1,6,11,14-16}$, with attendant oxidation to $\mathrm{CO}_{2}$ causing climatic warming through a 
greenhouse feedback ${ }^{3}$. Because of the relative rapidity of its onset, and the estimated quantity of sedimentary-sourced carbon involved, the PETM has attracted interest as a natural analogue to the ongoing anthropogenic perturbation to Earth's surficial carbon cycle.

In recent years, a number of transient warming events comparable in character to the PETM, but less extreme in magnitude and duration, have been discovered throughout the early Palaeogene (at approx. 65.2, 58.2, 53.7, 53.2, $52.5 \& 41.8 \mathrm{Ma}^{4-13}$ ). These 'hyperthermals ${ }^{34}$ have not been found during the later part of the Eocene (after $\sim 40 \mathrm{Ma}$ ) as global climate cooled (Fig. 1a). The number of these hyperthermals, and the relative temporal spacing between some of them, is suggestive of the operation of common mechanisms ${ }^{5,6,11}$. Although various mechanisms have been proposed for the origin of these comparatively modest events ${ }^{5,7,12}$, it is widely considered that they too were triggered by large-scale releases of carbon from sedimentary reservoirs ${ }^{3,6,11,16,17}$, probably methane hydrates ${ }^{3,6,11,16}$. Yet, the typical magnitude of the $\delta^{13} \mathrm{C}$ anomalies across known hyperthermals (up to $\sim 1.0 \%$ ) is, in fact, not unusual for $\delta^{13} \mathrm{C}$ records from the better chronicled Neogene Period and, more importantly, these anomalies are not so large that they necessitate a source of carbon that is as extremely isotopically depleted as methane hydrate $\left(\delta^{13} \mathrm{C}=-60 \%\right)$.

A 2.4 million year-long benthic foraminifer stable isotope record (Supplementary Discussion) from Demerara Rise in the tropical western Atlantic (Ocean Drilling Program Site 1258) shows that events exhibiting the characteristics of previously identified hyperthermals are abundant in the Palaeogene deep-sea palaeoceanographic record. 
Spanning the early Eocene to middle Eocene transition (47.6 to $50.0 \mathrm{Ma}$ ), these records indicate that average temperatures in the early Eocene equatorial Atlantic were 12 to 14 ${ }^{\circ} \mathrm{C}$ at about $3000 \mathrm{~m}^{8}$ water depth (Fig. 1b). This warm deep ocean state is punctuated by 13 excursions to lower $\delta^{18} \mathrm{O}$ values indicative of short-term warming by $\sim 2$ to $4{ }^{\circ} \mathrm{C}$ (Fig. 1b; Fig. 2a; events numbered in Fig. 1c). These transient warming events develop very rapidly $(<5$ to 10 thousand years $[\mathrm{kyr}])$ and decay to 'background' temperatures more slowly (over $\sim 30 \mathrm{kyr}$ ).

Our accompanying benthic foraminifer $\delta^{13} \mathrm{C}$ record shows that each warming event is marked by an excursion to lower $\delta^{13} \mathrm{C}$ values by 0.7 to $1.0 \%$ (Fig. 1c). Where planktic records are available for the most prominent negative excursions in the benthic $\delta^{13} \mathrm{C}$ record, these also reveal negative $\delta^{13} \mathrm{C}$ excursions of 0.6 to $0.9 \%$ (Fig. 2), suggesting that these events represent whole-ocean decreases in $\delta^{13} \mathrm{C}$ of total dissolved inorganic carbon $\left(\Sigma \mathrm{CO}_{2}\right)$.

All of the benthic $\delta^{13} \mathrm{C}$ excursions are associated with brown clay-rich layers at Demerara Rise (arrows in Fig. 1), a hallmark of other reported early Palaeogene hyperthermals ${ }^{1,6,7,10,12,13}$, that suggests increased calcium carbonate $\left(\mathrm{CaCO}_{3}\right)$ dissolution. Yet not all clay layers are associated with a numbered $\delta^{13} \mathrm{C}$ excursion (Fig. 1c). However, those that are not are still associated with a $\delta^{13} \mathrm{C}$ excursion, but one of smaller magnitude. This is consistent with the largest hyperthermals (those numbered in Fig. 1c) simply being prominent end-members in a spectrum of carbon cycle perturbations that scale up from orbitally paced 'background' cycles. Records of estimated $\mathrm{CaCO}_{3}$ concentrations from Demerara Rise (palaeo-water depth $\sim 3 \mathrm{~km}^{8}$ ) and sites in the southern Atlantic and 
central Pacific (palaeo-water depths $\sim 3$ and $2 \mathrm{~km}$, respectively [Supplementary Discussion]) reveal synchronous, globally widespread decreases in $\mathrm{CaCO}_{3}$ accumulation (Supplementary Fig. 2e to g). Calculations of carbonate dissolution associated with the clay layers in the Atlantic and Pacific (Supplementary Discussion), indicate that $\mathrm{CaCO}_{3}$ dissolution events (Fig. 3b to d) are coeval with the large negative benthic $\delta^{13} \mathrm{C}$ excursions at Demerara Rise (Fig. 3a). This correspondence strongly suggests that global increases in deep ocean acidity were associated with intervals of isotopically 'light' carbon pervading the world's oceans.

Our age model indicates that the Demerara Rise hyperthermals have overall durations of $\sim 40 \mathrm{kyr}$ (Fig. 1b and c; Fig. 2), consistent with pacing by the $41 \mathrm{kyr}$ obliquity cycle in Earth's axial tilt. The timing of individual hyperthermals is not perfectly cyclic, but does appear to occur within orbital frequency bands of 400 and 100 kyr (Fig. $1 \mathrm{~b}$ and c). For example, spectral analysis of the benthic foraminifer $\delta^{13} \mathrm{C}$ record shows spectral power at the $127 \mathrm{kyr}$ 'short' eccentricity frequency (Supplementary Fig. 3). Furthermore, even though our $2.4 \mathrm{Myr}-$ long $\delta^{13} \mathrm{C}$ record can only contain a maximum of six 'long' 405 kyr eccentricity cycles, power and highly significant coherency with the astronomical prediction is also found at this longer frequency (Supplementary Fig. 3). Moreover, shorter period fluctuations in the estimated $\% \mathrm{CaCO}_{3}$ record from Demerara Rise are modulated in amplitude at this $\sim 405$ kyr frequency (Supplementary Fig. 2e). This strong $405 \mathrm{kyr}$ response in carbon cycling compared to the relative amplitude of this cycle in the insolation forcing ${ }^{18}$ has been attributed ${ }^{5,19}$ to the long residence time ( 140 $\mathrm{kyr}^{14,15}$ ) of $\Sigma \mathrm{CO}_{2}$ in the oceans. Our new data demonstrate that the long $405 \mathrm{kyr}$ 
eccentricity cycle, a major component of secular carbon cycling in the ocean ${ }^{5,19}$, was also intimately involved in pacing Eocene hyperthermals.

These perturbations to oceanic carbon cycling could have been fuelled by carbon input from a number of different potential sources. Besides methane hydrates, erosion of sedimentary organic carbon $\left(\mathrm{C}_{\text {org }}\right)$ could supply carbon with a $\delta^{13} \mathrm{C}$ composition $(-25 \%)$ that is less depleted than that of methane $(-60 \%)$. A third potential source is redistribution of carbon within the exchangeable reservoirs at Earth's surface (ocean, atmosphere and biosphere). Redistribution of isotopically light carbon among the internal, readily exchangeable reservoirs should produce $\delta^{13} \mathrm{C}$ excursions with fundamentally different size, shape, duration and recovery trends than carbon input from an external, sedimentary reservoir.

Mass balance considerations (assuming masses of Eocene carbon reservoirs similar to modern) dictate that the $\sim 1 \%$ o $\delta^{13} \mathrm{C}$ excursions we observe are compatible with injection of a mass of carbon from methane hydrates (-60\%) of about 650 gigatonnes (Gt). But this volume of carbon is far too small to have driven our corresponding deep ocean warmings of 3 to $4{ }^{\circ} \mathrm{C}$ (Fig. 1b; Fig. 2a), particularly given that deep ocean warming of 6 to $7^{\circ} \mathrm{C}$ at the $\mathrm{PETM}^{3}$ was triggered by release of $>>2000^{1}$ to $6800^{17} \mathrm{Gt}$ of carbon. The large and widespread increases in $\mathrm{CaCO}_{3}$ dissolution associated with our hyperthermals also appear to demand a much larger input of carbon than the $650 \mathrm{Gt}$ permitted by a methane hydrate source.

The $\delta^{13} \mathrm{C}$ composition of sedimentary $\mathrm{C}_{\mathrm{org}}(-25 \%$ ) permits a much larger carbon release $(\sim 1600 \mathrm{Gt})$ to be accommodated within the observed $1 \% \delta^{13} \mathrm{C}$ excursions of 
hyperthermals, but problems also exist with this carbon source. The $\sim 140 \mathrm{kyr}$ residence time $(\tau)$ of carbon in Earth's exchangeable reservoirs ${ }^{14,15}$ suggests that the liberation of a substantial quantity of isotopically light carbon from an external, deeply buried source should have a persistent imprint on oceanic and atmospheric $\delta^{13} \mathrm{C}$ for a very long time (approaching $\tau)^{20}$ until it is ultimately sequestered back into the long-term sedimentary carbon reservoir by weathering reactions ${ }^{20}$. This behaviour is demonstrated at the PETM which shows a $\delta^{13} \mathrm{C}$ excursion $\sim 170 \mathrm{kyr}$ in duration ${ }^{2}$ with a very long recovery 'tail' $1,3,5,11$ that produces a very asymmetrical excursion and reflects the long timescales required for weathering to draw down this external $\mathrm{CO}_{2}$ and return it to the sedimentary reservoir as $\mathrm{CaCO}_{3}$. However, our $\delta^{13} \mathrm{C}$ excursions are too short (only $\sim 40 \mathrm{kyr}$ total duration), return to pre-excursion values too fast (within $30 \mathrm{kyr}$, Fig. 1c, Fig. 2a), and to a post-excursion baseline that is isotopically no different from pre-excursion, to be compatible with largescale injection of light carbon from a deeply buried source. The recoveries seen for other hyperthermals ${ }^{5,6,8,10-13}$ are also too rapid to represent sequestration of substantial amounts of sedimentary-sourced carbon.

The incompatibility of hyperthermals with external, sedimentary carbon sources indicates that the carbon that fuelled them was likely redistributed from within the readily exchangeable reservoirs at Earth's surface. The oceans are by far the largest of these exchangeable reservoirs - the present-day oceans contain 13 times as much carbon as the combined biosphere and atmosphere - all told about 40,000 Gt of carbon. Today, about 700-1800 Gt of this carbon (between 1 and 2 times the mass of the atmospheric reservoir) is stored as dissolved $\mathrm{C}_{\text {org }}\left(\delta^{13} \mathrm{C}=-25 \%\right)$, but this reservoir size would likely grow, 
perhaps many fold, under more oxygen-depleted deep ocean conditions. Redistribution of a mass of carbon equivalent to this entire modern reservoir ( 1600 Gt C) would be required to produce the $\sim 1.0 \% \delta^{13} \mathrm{C}$ excursions seen for our events and previously reported ones ${ }^{5,6,8,10-13}$. Within the oceans, the two principal reservoirs for storing large volumes of carbon are marginal basins or the abyssal ocean. Because of its sheer size, the deep abyssal reservoir of carbon has long been implicated in the regular, 100 parts per million by volume (ppmv) fluctuations of atmospheric $\mathrm{CO}_{2}$ and $\sim 5{ }^{\circ} \mathrm{C}$ surface temperature changes seen across the late Pleistocene glacial cycles. It has recently become clear that the abyssal Southern Ocean has played a pivotal role in Pleistocene carbon cycling though its gradual amassing of respired $\mathrm{CO}_{2}$ during glacials ${ }^{21-23}$ and subsequent release via increased ventilation ${ }^{21-23}$ during deglaciation.

Several observations suggest that the source of $\mathrm{CO}_{2}$ fuelling Eocene hyperthermals was the abyssal ocean. First, our dissolution records provide clues to the place of storage of $\mathrm{CO}_{2}$ in the exchangeable carbon reservoirs. Numerical modelling indicates that $\mathrm{CaCO}_{3}$ dissolution should be most intense close to the source of carbon release $^{15}$. In our estimates of $\mathrm{CaCO}_{3}$ dissolution, dissolution intensity appears to be consistently highest in the southern Atlantic (Fig. 3e) compared to the other sites. This raises the possibility that the abyssal reservoir of carbon was located in the Southern Ocean. Second, all our hyperthermals are approximately $40 \mathrm{kyr}$ in duration (Fig. $1 \mathrm{~b}$ and c, Fig. 2). The similarity of this period to the $41 \mathrm{kyr}$ obliquity cycle suggests that the forcing for individual hyperthermal events had its origin at high latitudes. This is consistent with an obliquity pacing of high latitude surface ocean stratification controlling 
$\mathrm{CO}_{2}$ ventilation, as proposed for the last deglaciation ${ }^{24}$.

If the source of $\mathrm{CO}_{2}$ driving Eocene hyperthermals was the deep ocean, a number of observations suggest that our Eocene sites may be somewhat analogous to intermediate-depth sites during Pleistocene glacials that were located above a deeper $\mathrm{CO}_{2}$ storage reservoir $^{21,25}$. First, although very few lower Eocene deep-sea sedimentary sections have paleo-water depths greater than about $3 \mathrm{~km}$, their lithologies are almost universally dominated by $\mathrm{CaCO}_{3}$, suggesting that any early Eocene corrosive abyssal reservoir of respired $\mathrm{CO}_{2}$ must have been restricted to depths $>3 \mathrm{~km}$. Second, the absence prior to our hyperthermals of either gradually decreasing benthic $\delta^{13} \mathrm{C}$ or increasing dissolution intensity (Fig. 1c, Fig. 2) indicates that our mid-depth (2 to $3 \mathrm{~km}$ ) sites did not 'sense' the gradual ( $\sim 10^{4}$ to $10^{5}$ year) build-up of a $\mathrm{CO}_{2}$ reservoir until its final release.

Early Eocene hyperthermals were superimposed on an already warm climate (Fig. 1a, b) with high background partial pressures of atmospheric $\mathrm{CO}_{2}\left(p \mathrm{CO}_{2}\right)$ (available proxies suggest 2 to 12 times pre-industrial levels, $\sim 500$ to $3500 \mathrm{ppmv}^{26}$ ). Assuming that Eocene climate sensitivity (to a $\mathrm{CO}_{2}$ doubling) lay within expected ranges $\left(1.5\right.$ to $4.5^{\circ} \mathrm{C}$ ), this range of high background $p \mathrm{CO}_{2}$ implies that, in comparison to ocean degassing during Pleistocene deglacials, much larger Eocene releases of carbon would have been required to rapidly raise deep ocean temperatures by the observed $3.5^{\circ} \mathrm{C}$ (e.g. $830-2500$ Gt for a background $\mathrm{pCO}_{2}$ of 500 ppmv, 1660-5000 Gt for 1000 ppmv and 3330-10,000 Gt for $2000 \mathrm{ppmv}$ ). Our estimate of carbon releases 1600 Gt appears most compatible with the lower end of background $p \mathrm{CO}_{2}$ concentrations ( $\left.\sim 500 \mathrm{ppmv}\right)$. 
In the modern oceans, dissolved $\mathrm{C}_{\text {org }}$ concentrations decrease during the water mass aging process, owing to progressive bacterial respiration primarily of young, labile components $^{27}$. This relationship with water mass age might argue against a larger-thanmodern Eocene reservoir of dissolved $\mathrm{C}_{\text {org }}$ driven solely by longer residence times of deep water in the Eocene ocean. However, under anoxic conditions, dissolved $\mathrm{C}_{\text {org }}$ may build-up. For example, concentrations of dissolved $\mathrm{C}_{\text {org }}$ in the anoxic depths (>2000 m) of the modern Black Sea are $\sim 2.5$ times those of the global deep ocean ${ }^{28}$. An early Eocene decoupling of marine burial rates of $\mathrm{C}_{\text {org }}$ versus pyrite indicates that the deep ocean during this interval may have regularly experienced pronounced anoxia ${ }^{29}$. We suggest that this persistent anoxia in the early Eocene abyss ${ }^{29}$, at least partly driven by the lower solubility of oxygen at warmer temperatures (Fig. 1a, b), would have promoted the build-up of a reservoir of dissolved $\mathrm{C}_{\text {org }}$ large enough to have fuelled hyperthermal carbon releases $\sim 1600$ Gt. Anoxia in the Eocene abyss is consistent with modelling projections for the next few millenia indicating a large reduction in abyssal ventilation (by up to $75 \%)^{30}$ in response to climatic warming induced by an 'anthropogenic' atmospheric $p \mathrm{CO}_{2}(1700 \mathrm{ppmv})$ similar to that of the early Eocene. Furthermore, we suggest that the relatively long $\sim 100$ or $400 \mathrm{kyr}$ intervals between $\mathrm{CO}_{2}$ release events (Fig. 1) would also have contributed to the build-up of a large Eocene abyssal reservoir of dissolved $\mathrm{C}_{\text {org }}$ (see Supplementary Discussion).

Further support for the existence of a larger-than-modern Eocene deep (>3 km) ocean reservoir of dissolved $\mathrm{C}_{\mathrm{org}}$ is found in surface-to-deep profiles of seawater temperature and $\delta^{13} \mathrm{C}$ reconstructed from multiple species of planktic and benthic 
foraminifera (Supplementary Fig. 4). In comparison to Recent core-top data, Eocene data suggest a steeper vertical gradient of $\delta^{13} \mathrm{C}$ of DIC versus temperature along with a greater total surface-to-seafloor $\delta^{13} \mathrm{C}$ difference (Supplementary Fig. 4), together consistent with a deeper mean $\mathrm{C}_{\text {org }}$ remineralisation depth. The much greater species diversity of calcareous nannofossils relative to diatoms throughout the early Palaeogene ${ }^{31}$ may have accelerated the abyssal transfer of $\mathrm{C}_{\text {org }}$ from the surface owing to the greater ballasting efficiency of $\mathrm{CaCO}_{3}$ relative to opal ${ }^{32}$. Interestingly, a major switch to greater species diversity of diatoms relative to calcareous nannofossils (at $\sim 40 \mathrm{Ma})^{31}$ coincides with the last documented early Cenozoic 'hyperthermal' event ${ }^{10}$.

Although the PETM must have been fuelled by carbon injection from an external, sedimentary source(s), we suggest that astronomically paced changes in ocean ventilation of dissolved $\mathrm{C}_{\text {org }}$ may explain the numerous less extreme hyperthermals that are being discovered ${ }^{4-13}$ throughout the early Palaeogene. $\mathrm{CO}_{2}$ ventilation is a viable mechanism with which to sustain the repeated, frequent carbon releases that define hyperthermals over a geologically extended interval (Fig. $1 \mathrm{~b}$ and $\mathrm{c})^{4-13}$ since the recharge times of the abyssal ocean (via remineralisation of $\mathrm{C}_{\mathrm{org}}$ ) are rapid compared to the slow, multi-million year filling of sedimentary methane hydrate reservoirs ${ }^{33}$. The extraordinarily warm mean state of the Palaeogene oceans (Fig. 1a, b) also raises the question as to whether largescale methane hydrate reservoirs would even have existed at this time ${ }^{33}$. Despite the extreme nature of these repeated Palaeogene climatic warming events, our findings indicate that they were driven by changes in storage of carbon within the oceans. 


\section{METHODS SUMMARY}

$\delta^{18} \mathrm{O}$ and $\delta^{13} \mathrm{C}$ data were generated using mono-specific analyses of the benthic foraminifers Cibicidoides subspiratus and C. eoceanus at the National Oceanography Centre, Southampton. High resolution Eocene records of $\mathrm{CaCO}_{3}$ concentrations were calculated, by regression, using sediment physical property data and measurements of sediment $\mathrm{CaCO}_{3}$ content. We developed an astronomically calibrated age model for Site 1258 (Demerara Rise). Detailed chronologies for Sites 1267 and 1210 were generated by tuning clear, correlatable events in their respective $\% \mathrm{CaCO}_{3}$ records to the astronomically calibrated \% $\mathrm{CaCO}_{3}$ record from Site 1258.

Full Methods are available at the end of this manuscript. 


\section{References}

1. Zachos, J.C. et al. Rapid acidification of the ocean during the Paleocene-Eocene thermal maximum. Science 308, 1611-1615 (2005).

2. Rohl, U., Westerhold, T., Bralower, T.J. \& Zachos, J.C. On the duration of the Paleocene-Eocene thermal maximum (PETM). Geochemistry Geophysics Geosystems 8, Q12002 (2007).

3. Zachos, J.C., Dickens, G.R. \& Zeebe, R.E. An early Cenozoic perspective on greenhouse warming and carbon-cycle dynamics. Nature 451, 279-283 (2008).

4. Thomas, E., and Zachos, J.C. and Bralower, T. J. Deep sea environments on a warm earth. in Warm Climates in Earth History (eds. Huber, B., MacLeod, K. \& Wing, S.) 132-160 (Cambridge Univ. Press, Cambridge, 2000).

5. Cramer, B.S., Wright, J.D., Kent, D.V. \& Aubry, M.P. Orbital climate forcing of delta C-13 excursions in the late Paleocene-early Eocene (chrons C24n-C25n). Paleoceanography 18, 1097 (2003).

6. Lourens, L.J. et al. Astronomical pacing of late Palaeocene to early Eocene global warming events. Nature 435, 1083-1087 (2005).

7. Petrizzo, M.R. An early late Paleocene event on Shatsky Rise, northwest Pacific Ocean (ODP Leg 198): evidence from planktonic foraminiferal assemblages. in Proc. ODP, Sci. Results, 198 (eds. Bralower, T.J., Premoli Silva, I. \& Malone, M.J.) 1-29 (Ocean Drilling Program, College Station, TX, 2005).

8. Sexton, P.F., Wilson, P.A. \& Norris, R.D. Testing the Cenozoic multisite composite $\delta 180$ and $\delta 13 \mathrm{C}$ curves: New monospecific Eocene records from a single locality, Demerara Rise (Ocean Drilling Program Leg 207). Paleoceanography 21, PA2019 (2006).

9. Westerhold, T. et al. On the duration of magnetochrons C24r and C25n and the timing of early Eocene global warming events: Implications from the Ocean Drilling Program Leg 208 Walvis Ridge depth transect. Paleoceanography 22, PA2201 (2007).

10. Edgar, K.M., Wilson, P.A., Sexton, P.F. \& Suganuma, Y. No extreme bipolar glaciation during the main Eocene calcite compensation shift. Nature 448, 908911 (2007).

11. Nicolo, M.J., Dickens, G.R., Hollis, C.J. \& Zachos, J.C. Multiple early Eocene hyperthermals: Their sedimentary expression on the New Zealand continental margin and in the deep sea. Geology 35, 699-702 (2007).

12. Quillévéré, F., Norris, R.D., Kroon, D. \& Wilson, P.A. Transient ocean warming and shifts in carbon reservoirs during the early Danian. Earth and Planetary Science Letters 265, 600-615 (2008).

13. Stap, L. et al. High-resolution deep-sea carbon and oxygen isotope records of Eocene Thermal Maximum 2 and H2. Geology 38, 607-610 (2010).

14. Dickens, G.R., O’Neil, J.R., Rea, D.K. \& Owen, R.M. Dissociation of oceanic methane hydrate as a cause of the carbon isotope excursion at the end of the Paleocene. Paleoceanography 10, 965-971 (1995).

15. Dickens, G.R. Methane oxidation during the late Palaeocene thermal maximum. Bulletin de la Societe Geologique de France 171, 37-49 (2000). 
16. Dickens, G.R. Rethinking the global carbon cycle with a large, dynamic and microbially mediated gas hydrate capacitor. Earth and Planetary Science Letters 213, 169-183 (2003).

17. Panchuk, K., Ridgwell, A. \& Kump, L.R. Sedimentary response to PaleoceneEocene Thermal Maximum carbon release: A model-data comparison. Geology 36, 315-318 (2008).

18. Laskar, J. et al. A long-term numerical solution for the insolation quantities of the Earth. Astronomy \& Astrophysics 428, 261-285 (2004).

19. Palike, H. et al. The heartbeat of the Oligocene climate system. Science 314, 1894-1898 (2006).

20. Archer, D. Fate of fossil fuel $\mathrm{CO} 2$ in geologic time. Journal of Geophysical Research-Oceans 110, C09S05 (2005).

21. Hodell, D.A., Venz, K.A., Charles, C.D. \& Ninnemann, U.S. Pleistocene vertical carbon isotope and carbonate gradients in the South Atlantic sector of the Southern Ocean. Geochemistry Geophysics Geosystems 4, 1004 (2003).

22. Toggweiler, J.R., Russell, J.L. \& Carson, S.R. Midlatitude westerlies, atmospheric CO2, and climate change during the ice ages. Paleoceanography 21(2006).

23. Skinner, L.C., Fallon, S., Waelbroeck, C., Michel, E. \& Barker, S. Ventilation of the Deep Southern Ocean and Deglacial CO2 Rise. Science 328, 1147-1151 (2010).

24. Sigman, D.M., de Boer, A.M. \& Haug, G.H. Antarctic stratification, atmospheric water vapor, and Heinrich events: A hypothesis for late Pleistocene deglaciations. in Past and Future Changes of the Oceanic Meridional Overturning Circulation: Mechanisms and Impacts, Vol. AGU Geophysical Monograph 173 (eds. Schmittner, A., J., Chiang, H.C. \& Hemming, S.R.) 335-350 (AGU, 2007).

25. Marchitto, T.M., Lehman, S.J., Ortiz, J.D., Fluckiger, J. \& van Geen, A. Marine radiocarbon evidence for the mechanism of deglacial atmospheric $\mathrm{CO} 2$ rise. Science 316, 1456-1459 (2007).

26. Royer, D.L. CO2-forced climate thresholds during the Phanerozoic. Geochimica Et Cosmochimica Acta 70, 5665-5675 (2006).

27. Hansell, D.A. \& Carlson, C.A. Deep-ocean gradients in the concentration of dissolved organic carbon. Nature 395, 263-266 (1998).

28. Ducklow, H.W., Hansell, D.A. \& Morgan, J.A. Dissolved organic carbon and nitrogen in the Western Black Sea. Marine Chemistry 105, 140-150 (2007).

29. Kurtz, A.C., Kump, L.R., Arthur, M.A., Zachos, J.C. \& Paytan, A. Early Cenozoic decoupling of the global carbon and sulfur cycles. Paleoceanography 18, 1090, doi:10.1029/2003PA000908 (2003).

30. Schmittner, A., Oschlies, A., Matthews, H.D. \& Galbraith, E.D. Future changes in climate, ocean circulation, ecosystems, and biogeochemical cycling simulated for a business-as-usual CO2 emission scenario until year 4000 AD. Global Biogeochemical Cycles 22, GB1013, doi:10.1029/2007GB002953 (2008).

31. Falkowski, P.G. et al. The evolution of modern eukaryotic phytoplankton. Science 305, 354-360 (2004). 
32. Klaas, C. \& Archer, D.E. Association of sinking organic matter with various types of mineral ballast in the deep sea: Implications for the rain ratio. Global Biogeochemical Cycles 16(2002).

33. Buffett, B. \& Archer, D. Global inventory of methane clathrate: sensitivity to changes in the deep ocean. Earth and Planetary Science Letters 227, 185-199 (2004).

Supplementary Information is linked to the online version of the paper at www.nature.com/nature.

Acknowledgements We thank M. Bolshaw for laboratory assistance and the Shipboard Party and crew of Ocean Drilling Program (ODP) Leg 207 for a successful drilling expedition. Discussions with H. Brinkhuis, G. Dickens, M. Huber, S. Kirtland, E. Rohling and J. Zachos were particularly helpful. This research used samples and data provided by the ODP. ODP (now IODP) is sponsored by the US National Science Foundation (NSF) and participating countries under the management of Joint Oceanographic Institutions (JOI), Inc. Financial support for this research was provided by a European Commission Marie Curie Outgoing International Fellowship (to P.F.S.), a Leverhulme Trust Fellowship (to P.F.S.), a Natural Environment Research Council UK ODP grant (to P.A.W. \& P.F.S.), the DFG-Leibniz Center for Surface Process \& Climate Studies at the University of Potsdam, and the Deutsche Forschungsgemeinschaft (DFG) (U.R. \& T.W.). 


\section{Figure captions}

Figure 1. High-resolution records across the early to middle Eocene transition from ODP Site 1258, Demerara Rise, tropical Atlantic. a, Deep sea benthic foraminifer composite $\delta^{18} \mathrm{O}$ data for the past 80 Myr from multiple sites ${ }^{3,8,10}$ (for full list of data sources, see Supplementary Note 1). Vertical dashed line denotes the Palaeocene-Eocene Thermal Maximum (PETM). Light grey shaded area indicates the early Palaeogene Period (45 to $65 \mathrm{Ma}$ ). Dark grey shaded box represents the study interval for this work. $\delta^{18} \mathrm{O}$-temperature scale is for ice-free conditions $^{3}(-1.27 \%$ VPDB). b to d, data from ODP Site 1258, Demerara Rise, with an astronomically calibrated age model (see Methods). b, Benthic foraminifer $\delta^{18} \mathrm{O}$ and calculated palaeotemperatures (see Methods). All benthic $\delta^{18} \mathrm{O}$ data in $\mathrm{a}$ and $\mathrm{b}$ are corrected to equilibrium calcite. c, Benthic foraminifer $\delta^{13} \mathrm{C}$. Note the repeated, rapid excursions to lower values. Events numbered (according to the magnetochron within which they occur) are those with an excursion exceeding $0.7 \%$. Black arrows mark the stratigraphic positions of clayrich $\mathrm{CaCO}_{3}$ dissolution horizons $(\mathrm{n}=18)$ made visible by their brown colour in the Demerara Rise sedimentary sequence, 13 of which correspond precisely to the numbered, rapid excursions to lower benthic $\delta^{13} \mathrm{C}$ values in $\mathrm{c}$. The remaining 5 clay layers are also associated with trends to lower $\delta^{13} \mathrm{C}$, but of noticeably smaller magnitude. d, Estimated $\mathrm{CaCO}_{3}$ content of sediment. Two asterisks denote 'hyperthermal' events shown in more detail in Fig. 2. 
Figure 2. Detail of isotope data across two 'hyperthermal' events (asterisks in Fig. 1). X-axis labels are at $40 \mathrm{kyr}$ spacing, highlighting the similarity of the duration (i.e. 'trough to trough') of these events to the obliquity frequency. We define the 'onset' phase of events as 'trough to peak', with their 'recovery' being 'peak to trough'.

Figure 3. Eocene records of benthic foraminifer $\delta^{13} \mathrm{C}$ and $\mathrm{CaCO}_{3}$ dissolution. a, Benthic $\delta^{13} \mathrm{C}$ from Fig. 1c (Demerara Rise, ODP Site 1258, western tropical Atlantic). $\mathbf{b}$ to $\mathbf{d}$, Records of calculated $\mathrm{CaCO}_{3}$ dissolution from ODP Site 1258 (b), ODP Site 1267, southern Atlantic (c), ODP Site 1210, Pacific (d), and smoothed versions (25 pt running mean) of all three (e). Shaded envelopes in $\mathbf{e}$ are $1 \sigma$ variance about the mean. Simultaneous increases in $\mathrm{CaCO}_{3}$ dissolution occur at all three sites and are marked by visible, brown 'clay' layers in sediment cores at each of the sites (marked by solid black arrows). Blue arrows mark our assumed 'zero-dissolution points' for each site (e.g. the primary, unaltered fractional component of $\mathrm{CaCO}_{3}$ in the sediment [see Supplementary Fig. 2 and Supplementary Information]). Light blue horizontal bars mark the interval at each site within which the Last Appearance Datum (LAD) of the nannofossil $D$. lodoensis occurs, providing a primary point of stratigraphic correlation between $\begin{array}{llll}\text { sites. } & \text { Inset } & \text { from }\end{array}$ http://www.odsn.de/odsn/services/paleomap/paleomap.html. 
Fig. 1

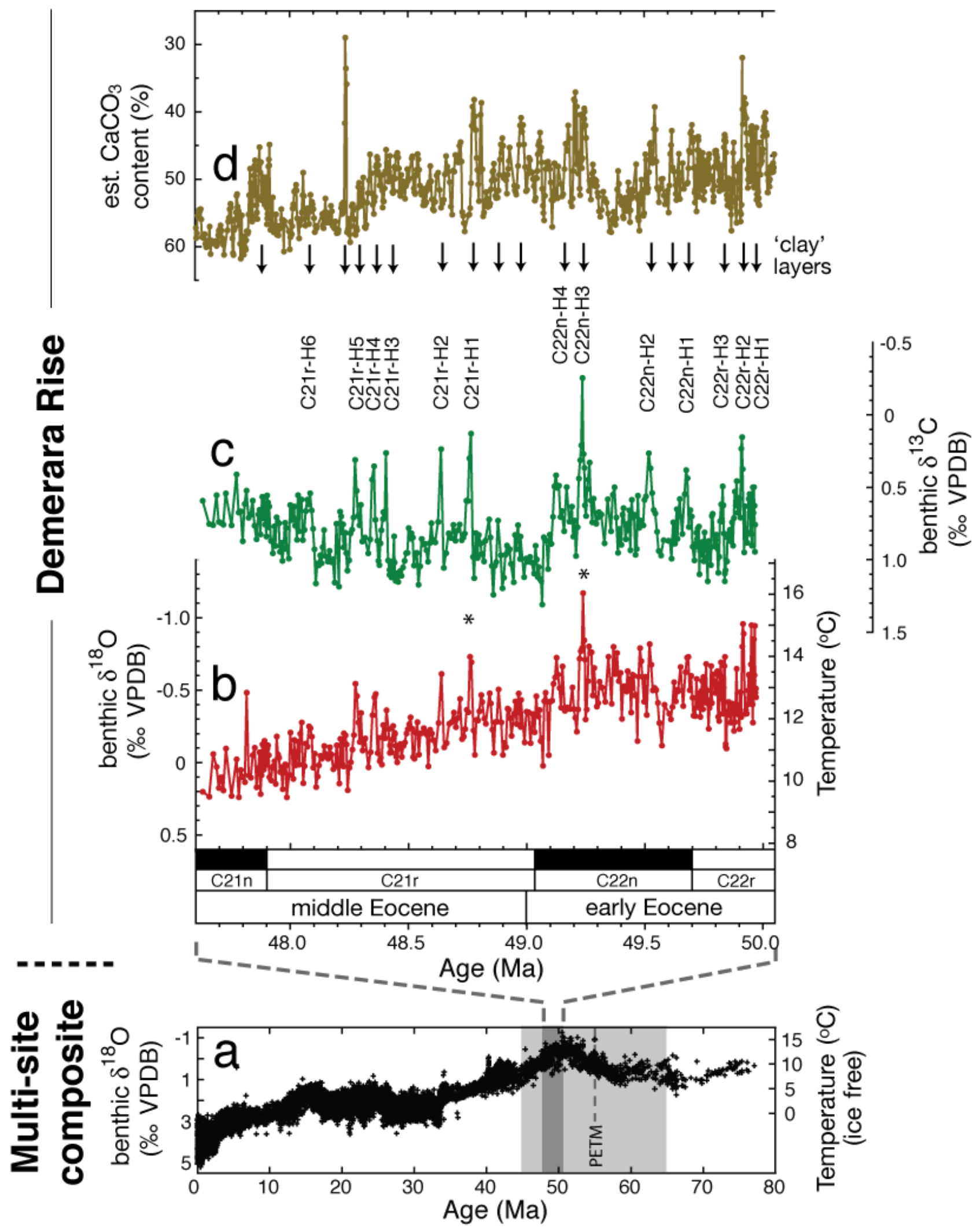


Fig. 2
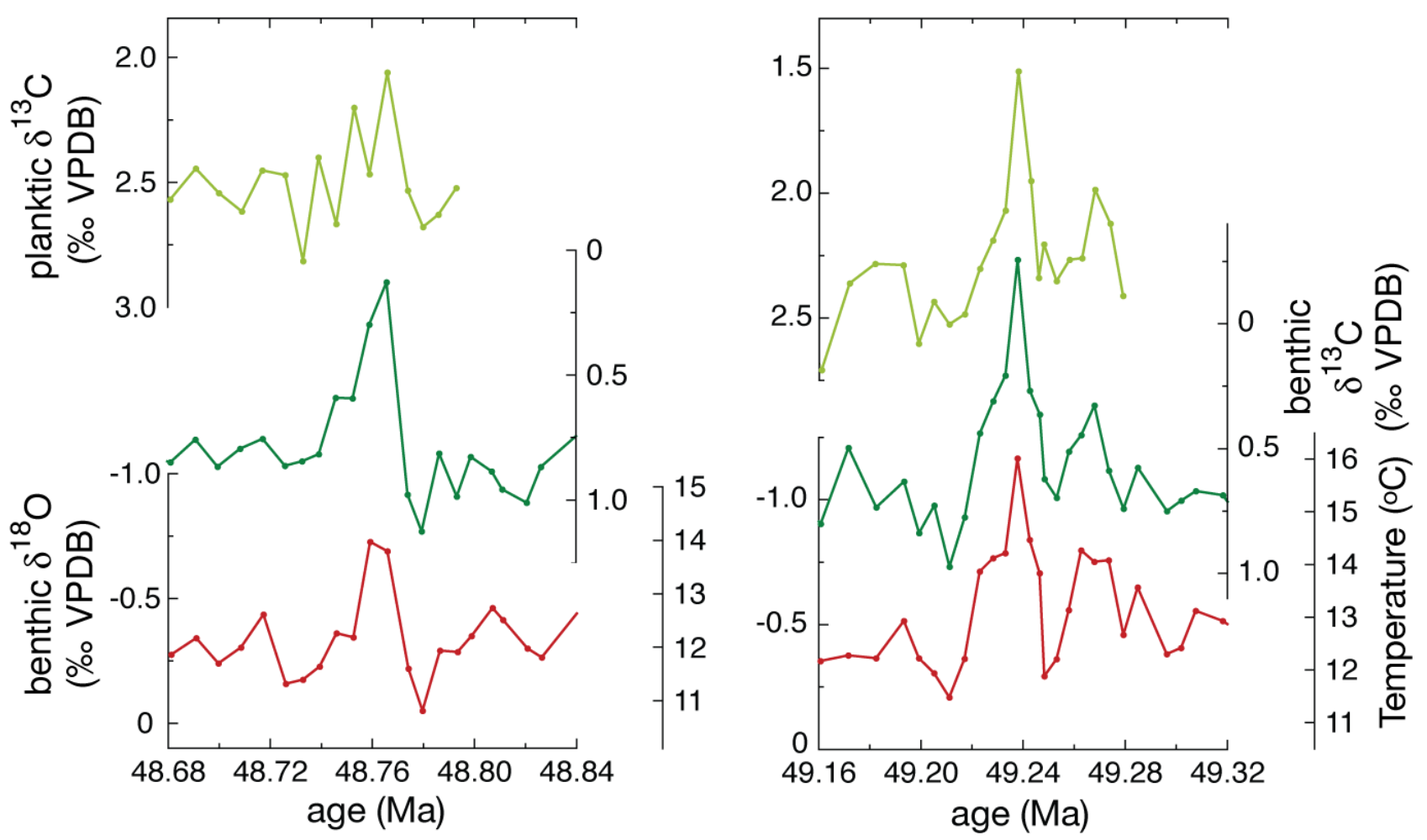
Fig. 3






\section{METHODS}

Stable isotope data. Benthic foraminifera were picked from the 250 to $400 \mu \mathrm{m}$ size fraction. Stable isotope data were generated at the National Oceanography Centre, Southampton using a Europa Geo 20-20 mass spectrometer equipped with an automatic carbonate preparation system. For each analysis, between 4 and 11 mono-specific specimens were analyzed after ultrasonic cleaning in deionized water. All data are reported relative to the Vienna Peedee Belemnite standard (VPDB). External analytical precision, based on replicate analyses of in-house standards calibrated to NBS-19, is better than $\pm 0.1 \%$ for $\delta^{18} \mathrm{O}$ and $\delta^{13} \mathrm{C}$.

Early Eocene through middle Eocene sediments at ODP Site 1258 (Demerara Rise) host well preserved benthic foraminifera ${ }^{8}$. Cibicidoides subspiratus was used as the primary species for stable isotope analysis. However, in certain intervals, notably in the younger part of our record (after 48.5 Ma), a decline in abundance of C. subspiratus dictated that we also use Cibicidoides eoceanus. Although modern core top samples show significant inter-species stable isotope offsets between certain species of Cibicidoides ${ }^{34}$, our calculated inter-species offsets for the two Eocene species of Cibicidoides (from paired mono-specific analyses, $\mathrm{n}=168$ ) are statistically indistinguishable from zero for both $\delta^{18} \mathrm{O}$ and $\delta^{13} \mathrm{C}\left(\delta^{18} \mathrm{O}=-0.031[1 \sigma=0.128] ; \delta^{13} \mathrm{C}=0.009[1 \sigma=0.133]\right)$. This provides justification for our strategy of using these two species in combination. Benthic foraminiferal taxonomy follows that of $\operatorname{refs}^{35,36}$.

All $\delta^{18} \mathrm{O}$ data are corrected to equilibrium calcite using the Oridorsalis spp. Cibicidoides spp. correction factor of $+0.28 \%$ derived from an assessment of isotopic 
offsets for Eocene benthic foraminifera ${ }^{37}$. Use of this correction factor is based on evidence (summarised in ref. $^{8}$ ) that Eocene Oridorsalis umbonatus secreted its calcite in $\delta^{18} \mathrm{O}$ equilibrium with seawater. Paleotemperatures were calculated using eq. 1 of ref. ${ }^{38}$. This equation provides excellent agreement with a global core top Cibicidoides spp. $\delta^{18} \mathrm{O}$ calibration for a temperature range from 0 to $7^{\circ} \mathrm{C}^{38}$. In keeping with the view that there were no significant continental ice sheets during the early to early middle Eocene ${ }^{39,40}$, our $\delta^{18} \mathrm{O}$ records can be interpreted in terms of change in bottom water temperature at Demerara Rise.

Age models. Site 1258 recovered an unusually continuous, relatively expanded (sedimentation rates up to $2.5 \mathrm{~cm} / \mathrm{kyr}$ ) sedimentary section across the lower to middle Eocene boundary with unprecedented magneto-, bio- and cyclo-stratigraphic control for this interval ${ }^{41-43}$. We developed an astronomically calibrated age model for Site 1258 by tuning clear and pronounced obliquity ( $40 \mathrm{kyr}$ ) cycles in the magnetostratigraphically calibrated magnetic susceptibility (MS) time series (Supplementary Fig. 1a) to computed obliquity cycles from the most recent astronomical solution ${ }^{18}$. Our tuning strategy is validated by the presence in our tuned MS time series of substantial power (and coherency with our tuning target) at frequencies of 23, 21 and $19 \mathrm{kyr}$ (precession), $54 \mathrm{kyr}$ (obliquity) and $96 \mathrm{kyr}$ (eccentricity) (Supplementary Fig. 1b), even though these frequencies were not used in the tuning process. An absolute calibration to the astronomical solution is, at present, unattainable for the early to middle Eocene because of limitations in the precision of computed orbital variations pre- $40 \mathrm{Ma}^{18}$ and because of significant uncertainties in radiometric age calibrations ${ }^{44,45}$. Consequently, we develop a 
'floating' astronomically tuned timescale, using the $\mathrm{C} 21 \mathrm{r} / \mathrm{C} 22 \mathrm{n}$ magnetochron boundary $\left(\right.$ age $\left.=49.037 \mathrm{Ma}^{44}\right)$ identified at Site $1258^{42}$ as our anchor point.

Age models for the estimated $\% \mathrm{CaCO}_{3}$ records for ODP 1267 (Walvis Ridge) and ODP 1210 (Shatsky Rise) are derived by correlating the stratigraphic position of a biostratigraphic datum (Last Appearance Datum [LAD] of the nannofossil D. lodoensis) at both of these sites to its position at Site 1258 (Supplementary Table 1). Further age model refinement was achieved by tuning clear, correlatable events in $\% \mathrm{CaCO}_{3}$ records from Sites 1267 and 1210 to the astronomically calibrated $\% \mathrm{CaCO}_{3}$ record from Site 1258 (Supplementary Tables 2 and 3). This tuning strategy was held as relaxed as possible, using a minimum of tie points.

Eocene records of $\mathrm{CaCO}_{3}$ concentrations. We use sediment colour and magnetic susceptibility data in conjunction with measurements of sediment $\mathrm{CaCO}_{3}$ content $^{41}$ to calculate, by regression, sediment $\mathrm{CaCO}_{3}$ content at high resolution at Demerara Rise (Fig. 1d; Supplementary Fig. 2e). We use comparable data ${ }^{46,47}$ to perform the same regressions for two other deep sea drill sites (ODP 1267, Walvis Ridge, southern Atlantic and ODP 1210, Shatsky Rise, central Pacific) (Supplementary Fig. 2f and g). At all three sites, estimated $\mathrm{CaCO}_{3}$ concentrations prove to be a good predictor of measured $\mathrm{CaCO}_{3}$ concentrations (Supplementary Fig. 2a to c). For methods for calculating $\mathrm{CaCO}_{3}$ dissolution from our Eocene $\mathrm{CaCO}_{3}$ records, see Supplementary Information.

34. Curry, W.B., Slowey, N.C. \& Lohmann, G.P. Oxygen and carbon isotopic fractionation of aragonitic and calcitic benthic foraminifera on Little Bahama Bank, Bahamas (abstract). EOS, Transactions of the American Geophysical Union 74, 368 (1993). 
35. Tjalsma, R.C. \& Lohmann, G.P. Paleocene-Eocene bathyal and abyssal benthic foraminifera from the Atlantic Ocean, 90 (1983).

36. van Morkhoven, F.P.C.M., Berggren, W. A. and Edwards, A. S. Cenozoic cosmopolitan deep water benthic foraminifera, 421 (Pau, 1986).

37. Katz, M.E. et al. Early Cenozoic benthic foraminiferal isotopes: Species reliability and interspecies correction factors. Paleoceanography 18, art. no.-1024 (2003).

38. Bemis, B.E., Spero, H.J., Bijma, J. \& Lea, D.W. Reevaluation of the oxygen isotopic composition of planktonic foraminifera: Experimental results and revised paleotemperature equations. Paleoceanography 13, 150-160 (1998).

39. Zachos, J., Pagani, M., Sloan, L., Thomas, E. \& Billups, K. Trends, rhythms, and aberrations in global climate 65 Ma to present. Science 292, 686-693 (2001).

40. Browning, J.V., Miller, K.G. \& Pak, D.K. Global implications of lower to middle Eocene sequence boundaries on the New Jersey coastal plain: The icehouse cometh. Geology 24, 639-642 (1996).

41. Erbacher, J., Mosher, D.C., Malone, M.J., et al. Proc. ODP, Init. Repts., 207 [Online]. Available from World Wide Web: http://wwwodp.tamu.edu/publications/207_IR/207ir.htm., (2004).

42. Suganuma, Y., and Ogg, J.G. Campanian through Eocene magnetostratigraphy of Sites 1257-1261, ODP Leg 207, Demerara Rise (western equatorial Atlantic). in Proc. ODP, Sci. Results, 207 [Online]. Available from World Wide Web: 〈http://www-odp.tamu.edu/publications/207_SR/102/102.htm〉. (ed. Mosher, D.C., Erbacher, J., and Malone, M.J. (Eds.)) (2006).

43. Westerhold, T. \& Rohl, U. High resolution cyclostratigraphy of the early Eocene - new insights into the origin of the Cenozoic cooling trend. Climate of the Past $\mathbf{5}$, 309-327 (2009).

44. Berggren, W., Kent, D. \& Swisher III, C. A revised Cenozoic geochronology and chronostratigraphy. in Geochronology Time Scales and Global Stratigraphic Correlation (ed. Berggren, W.) 129-212 (Soc. for Sediment. Geol., Tulsa, Okla., 1995).

45. Machlus, M., Hemming, S.R., Olsen, P.E. \& Christie-Blick, N. Eocene calibration of geomagnetic polarity time scale reevaluated: Evidence from the Green River Formation of Wyoming. Geology 32, 137-140 (2004).

46. Zachos, J.C., Kroon, D., Blum, P. \& al., e. Proc. ODP, Init. Repts., 208, (Ocean Drilling Program, College Station, TX, 2004).

47. Bralower, T.J., Premoli Silva, I., Malone, M.J. \& al., e. Proc. ODP, Init. Repts., 198, (Ocean Drilling Program, College Station, TX 2002). 


\section{Supplementary Information for}

\section{Multiple Eocene 'hyperthermal' events driven by ocean ventilation}

Philip F. Sexton*, Richard D. Norris, Paul A. Wilson, Heiko Pälike, Thomas Westerhold, Ursula Röhl, Clara T. Bolton \& Samantha Gibbs

*email: P.F.Sexton@open.ac.uk

\section{Supplementary Discussion}

- Controls on stable isotope records from Demerara Rise

- Eocene proxy records of $\mathrm{CaCO}_{3}$ dissolution

- Locating an Eocene abyssal reservoir of carbon

\section{Supplementary Figures 1 to 4}

\section{$\underline{\text { Supplementary Tables } 1 \text { to } 3}$}

\section{Supplementary Notes 1 to 2}




\section{Supplementary Discussion}

\section{Controls on stable isotope records from Demerara Rise}

We interpret the rapid and large excursions to lower values in our benthic foraminifer $\delta^{13} \mathrm{C}$ record from Demerara Rise to be representative of 'global' trends in $\delta^{13} \mathrm{C}$ of Total Dissolved Inorganic Carbon $\left(\Sigma \mathrm{CO}_{2}\right)$, as opposed to this site being at the boundary between two fluctuating water masses with contrasting $\delta^{13} \mathrm{C}$ signatures. All of our negative excursions in $\delta^{13} \mathrm{C}$ are coeval with globally widespread calcium carbonate $\left(\mathrm{CaCO}_{3}\right)$ dissolution events in the western tropical Atlantic, the southern Atlantic and the Pacific (Fig. 3), suggesting that the $\delta^{13} \mathrm{C}$ and dissolution anomalies represent injection (or, more accurately, redistribution) of isotopically light carbon into upper abyssal depths and shallower, and not regional water mass fluctuations.

The prominent and concurrent benthic foraminifer $\delta^{18} \mathrm{O}$ and $\delta^{13} \mathrm{C}$ excursions in our Demerara Rise data correlate with $\mathrm{CaCO}_{3}$ dissolution horizons. Yet these isotope excursions are unlikely to be an artefact of foraminiferal diagenetic alteration for two reasons. First, if $\mathrm{CaCO}_{3}$ dissolution (and recrystallisation of benthic foraminifera) was to occur within the sediment column under the influence of sedimentary pore waters (having a lower $\delta^{13} \mathrm{C}$ value than seawater, because of organic carbon $\left[\mathrm{C}_{\text {org }}\right]$ remineralisation), this would be expected to impart anomalously low $\delta^{13} \mathrm{C}$ values, but not lower $\delta^{18} \mathrm{O}$, into recrystallised foraminiferal tests. Furthermore, our evidence for concurrent dissolution events in several different ocean basins (Fig. $3 b$ to d) suggests that, if any post-mortem diagenetic alteration of Demerara Rise benthic foraminifera had occurred, it would have 
likely taken place at the seafloor during these dissolution events. But no a priori reason exists why $\delta^{13} \mathrm{C}$ (and especially $\delta^{18} \mathrm{O}$ ) should be offset to much lower values by recrystallisation at the seafloor. Second, visual inspection of benthic foraminifera under reflected light reveals no obvious signs of deteriorated taphonomy within the isotope 'excursion' intervals.

\section{Eocene proxy records of $\mathrm{CaCO}_{3}$ dissolution}

Our records of estimated $\% \mathrm{CaCO}_{3}$ display similar secular trends at all three locations (Supplementary Fig. 2e to g), although amplitudes of variance differ, presumably largely governed by the initial fractional component of $\mathrm{CaCO}_{3}$ in the sediment and by paleo-water depth (Demerara $\sim 3000 \mathrm{~m}^{8}$, Walvis $\sim 3000 \mathrm{~m}^{46}$, Shatsky $\sim 2000 \mathrm{~m}^{47}$ ). Because of the non-linear relationship between $\mathrm{CaCO}_{3}$ dissolution and sediment $\mathrm{CaCO}_{3}$ content ${ }^{48}$, we use our estimated $\% \mathrm{CaCO}_{3}$ time series (Supplementary Fig. $3 \mathrm{e}$ to g) to calculate the extent of $\mathrm{CaCO}_{3}$ dissolution at each site (Fig. $3 \mathrm{~b}$ to d). We do this by attempting to identify the primary, unaltered fractional component of $\mathrm{CaCO}_{3}$ in the sediment (our 'zero-dissolution point'). We then calculate changes in \% dissolution of the sedimentary $\mathrm{CaCO}_{3}$ component away from this zero-dissolution point using our estimated $\% \mathrm{CaCO}_{3}$ time series. Calculating $\mathrm{CaCO}_{3}$ dissolution in this manner involves two assumptions. First, we assume that the zero dissolution point is represented by the maximum $\% \mathrm{CaCO}_{3}$ value in each of our $2.4 \mathrm{Myr}$-long estimated $\% \mathrm{CaCO}_{3}$ time series (shown by blue arrows in Supplementary Fig. $2 \mathrm{e}$ to g). Our use of estimated $\% \mathrm{CaCO}_{3}$ data for our zero dissolution point, rather than the much lower resolution measured $\%$ 
$\mathrm{CaCO}_{3}$ data $^{41,46,47}$, is validated by the fact that estimated $\% \mathrm{CaCO}_{3}$ is a good predictor of measured $\% \mathrm{CaCO}_{3}$ (Supplementary Fig. 2a to c). We assume that these zero dissolution points represent intervals when the local lysocline lay deeper than the seafloor at each particular drill site. Second, we assume that the rain ratio of $\mathrm{CaCO}_{3}$ to $\mathrm{C}_{\text {org }}$ to the seafloor remained constant through the study interval at each site. While we acknowledge that this is unlikely, the sampling interval for our estimated $\% \mathrm{CaCO}_{3}$ time series $(\sim 2.5 \mathrm{kyr}$ at Demerara; $~ 5.0 \mathrm{kyr}$ at Shatsky and Walvis) should average out seasonal to inter-annual variability in rain ratios.

\section{Locating an Eocene abyssal reservoir of carbon}

Progressive build-up of carbon in the abyssal ocean and its episodic, rapid release to shallower water depths should, via $\mathrm{CaCO}_{3}$ compensation ${ }^{49}$, impart a distinctive pattern to the abyssal sedimentary record - long intervals of $\mathrm{CaCO}_{3}$-free to $\mathrm{CaCO}_{3}$-poor sedimentation followed by a pulse of $\mathrm{CaCO}_{3}$ upon degassing. The release of a large abyssal reservoir of respired $\mathrm{CO}_{2}$ during the last deglaciation led to the well-known deglacial ${ }^{\prime} \mathrm{CaCO}_{3}$ preservation spike, ${ }^{50,51}$. In searching for Eocene abyssal $\mathrm{CaCO}_{3}$ pulses we are hamstrung by the lack of very deep sites drilled during modern 'palaeoceanographic' expeditions. Nevertheless, a few rare abyssal sites provide preliminary indications that abyssal $\mathrm{CaCO}_{3}$ preservation spikes may have occurred during Eocene hyperthermals. Early Eocene sediments recovered from sites on the Iberian margin (DSDP Site 398 and ODP Site 1068) and off Bermuda (DSDP Site 386) (paleodepths $=\sim 4500 \mathrm{~m}$ ) comprise upward-darkening sequences of claystone overlying nannofossil claystone or nannofossil chalk ${ }^{52-54}$. The calcareous layers have frequently 
been interpreted as turbidites, primarily because some have graded beds ${ }^{55}$. Indeed, erosive contacts of calcareous layers with underlying clay, occasionally with pebbles overlying the calcareous layer, are indicative of turbidites. Yet many of the $\mathrm{CaCO}_{3}$-rich layers at these sites have graded basal contacts with the underlying clay, raising the possibility that they represent pulses of in-situ, abyssal $\mathrm{CaCO}_{3}$ sedimentation following a rapid reduction in the acidity of the abyss. But these abyssal sites typically have poor age control, partly because they generally lack the calcareous microfossils useful for biostratigraphic dating and partly because of incomplete sediment recovery associated with early drilling technology and the out-dated strategy of spot-coring. Despite these previous impediments, future detailed chronostratigraphic research should enable secure correlations between these abyssal sites and those (utilized here) at mid-depths in order to better understand the dynamics of Eocene oceanic carbon cycling. 

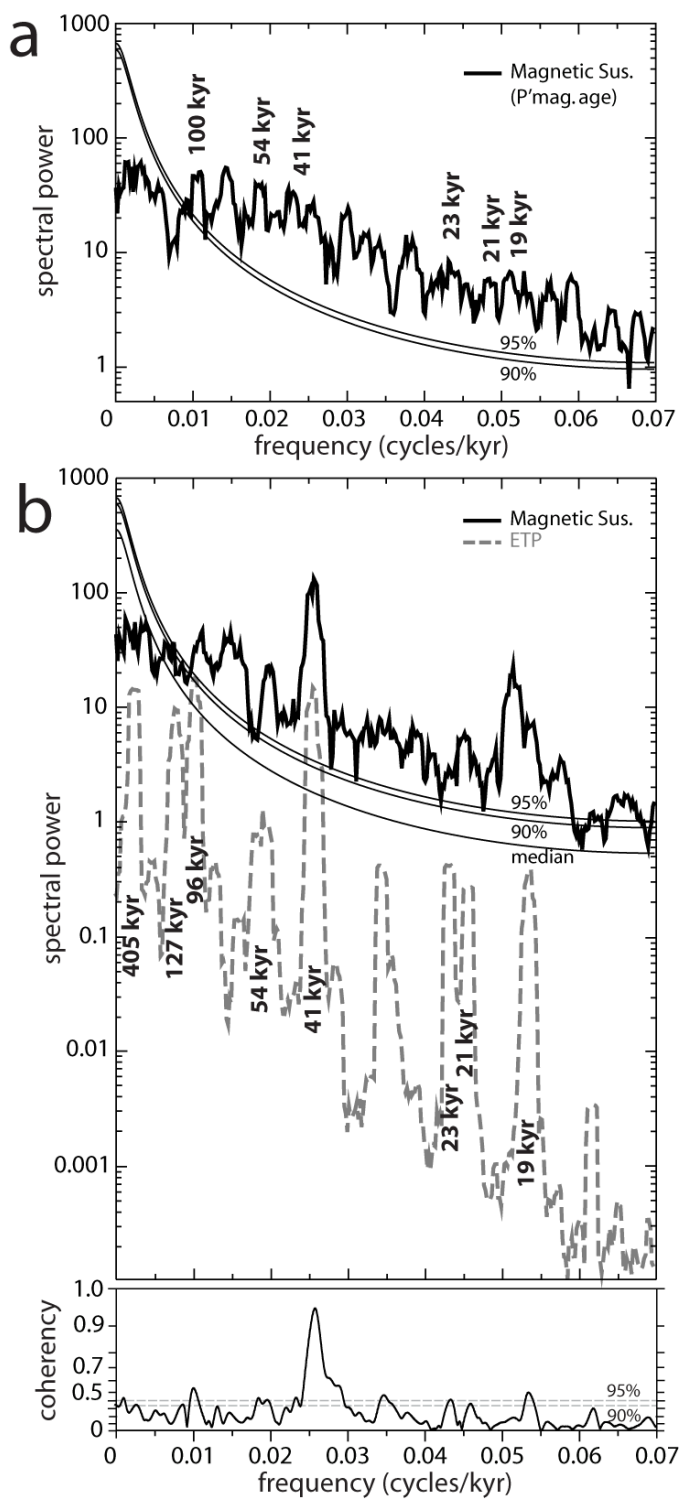

Supplementary Figure 1. Spectra of the magnetic susceptibility (MS) records used in the astronomical tuning process. a, Spectrum of MS data from Demerara Rise (ODP Site 1258) versus the paleomagnetic age model ${ }^{42}$ for this site. Substantial power exists at the obliquity frequencies (41 and $54 \mathrm{kyr}$ ), in addition to precession (19, 21 and $23 \mathrm{kyr}$ ) and eccentricity $(\sim 100 \mathrm{kyr})$ frequencies. b, Cross-spectrum of our astronomically tuned MS time series versus ETP, created using the multi-taper method ${ }^{56}$ (and also using software from ref. ${ }^{57}$ ). ETP represents a calculated mix of the main orbital parameters - eccentricity, obliquity (tilt) and climatic precession ${ }^{18}$. MS data were used to create an astronomical age model by tuning clear, pronounced obliquity cycles in the data to calculated obliquity in the latest ${ }^{18}$ astronomical solution. 95 and $90 \%$ confidence intervals are shown for both MS spectra. Spectrum of the tuned MS time series (b) shows strong power at frequencies of 19, 21 and $23 \mathrm{kyr}$ (precession), $54 \mathrm{kyr}$ (obliquity) and $96 \mathrm{kyr}$ (eccentricity) (frequencies not used in the tuning process), thereby providing independent validation of our tuning strategy. The tuned MS spectrum (b) is also coherent (above the 95\% confidence level) with the ETP tuning target at these same frequencies of 19, 23, 54 and 96 kyr. 

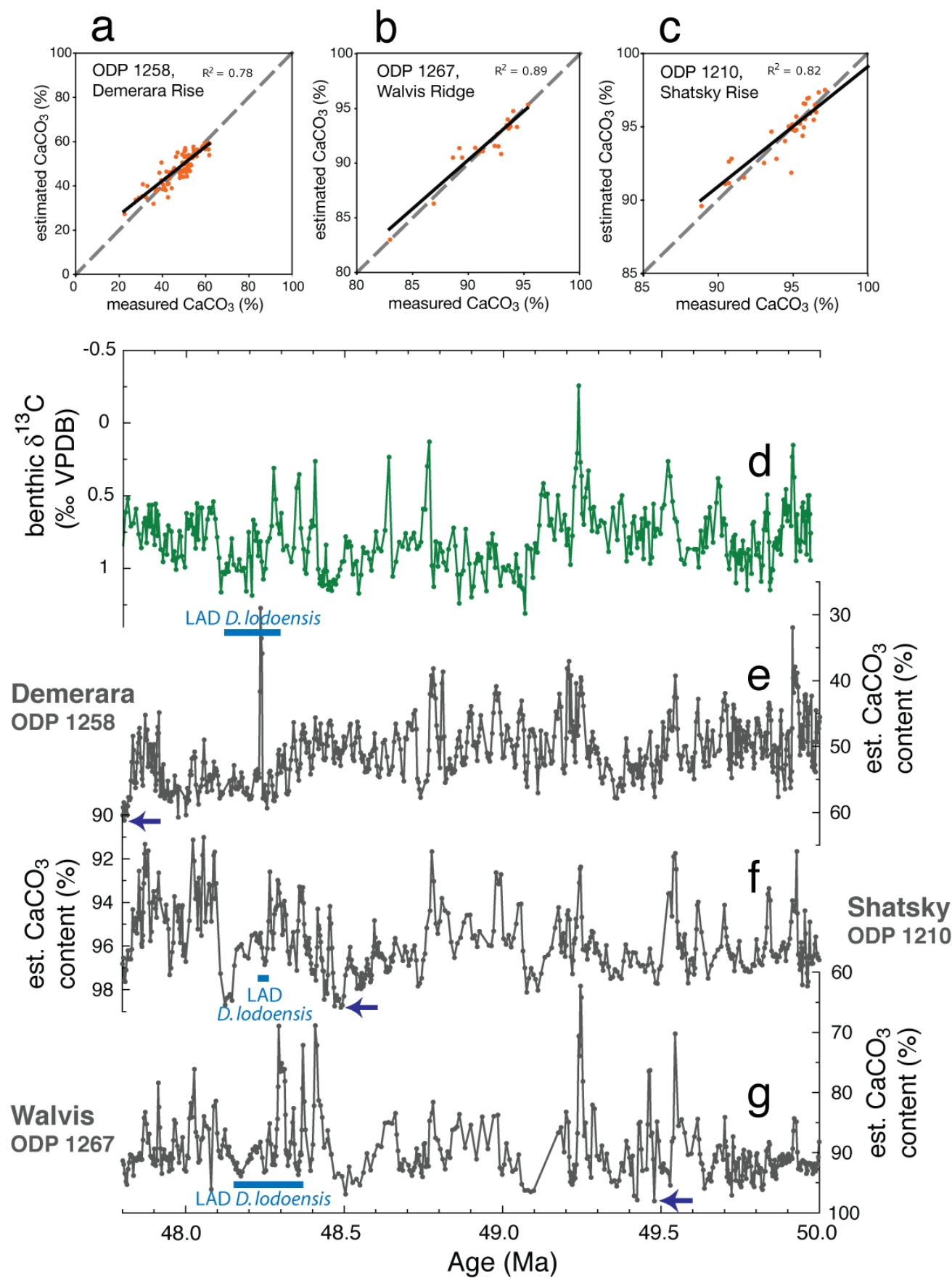

Supplementary Figure 2. Eocene records of estimated $\% \mathrm{CaCO}_{3}$. a to c show that estimated $\% \mathrm{CaCO}_{3}$ is a good predictor of measured $\% \mathrm{CaCO}_{3}$ at all three sites. Estimated $\% \mathrm{CaCO}_{3}$ records (shown vs. d, benthic $\delta^{13} \mathrm{C}$ from Fig. 1) from e, Demerara Rise (ODP Site 1258, tropical Atlantic), f, Shatsky Rise (ODP Site 1210, Pacific) and g, Walvis Ridge (ODP Site 1267, southern Atlantic). Age models for estimated $\% \mathrm{CaCO}_{3}$ records in $\mathrm{f}$ and $\mathrm{g}$ are derived by tuning clear, correlatable events in both records to the astronomically calibrated \% $\mathrm{CaCO}_{3}$ record in e (Demerara Rise, Site 1258). This tuning strategy was held as relaxed as possible, using a minimum of tie points. 'LAD' - Last Appearance Datum. Blue arrows mark our assumed 'zero-dissolution points' for each site, used in calculating ' $\% \mathrm{CaCO}_{3}$ dissolution' (see Fig. 2 and Supplementary Discussion). 


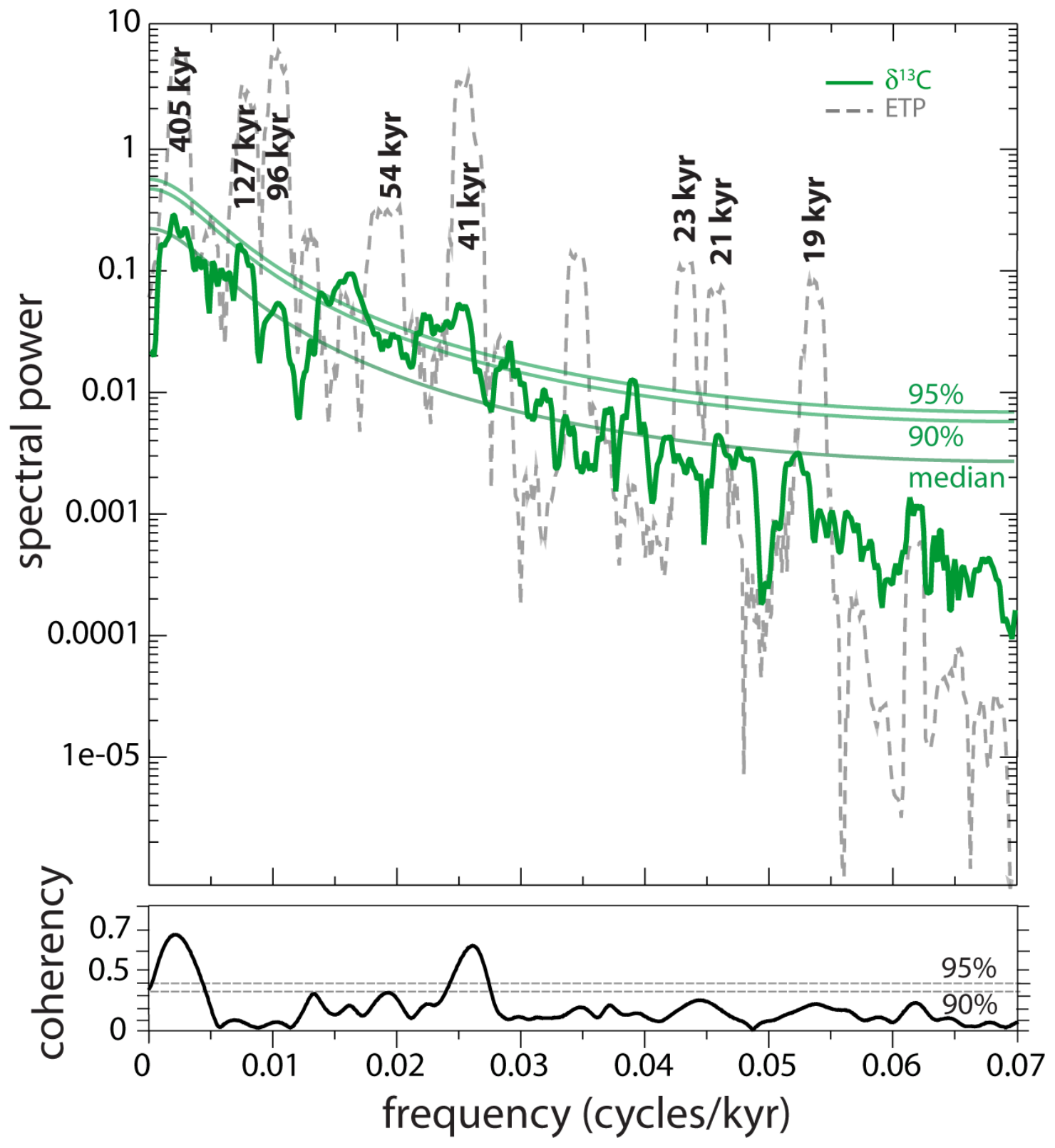

Supplementary Figure 3. Cross-spectrum of the benthic foraminifer $\delta^{13} \mathrm{C}$ record from Fig. 1c versus ETP, created using the multi-taper method ${ }^{56}$ (and using software from ref. $^{57}$ ). ETP represents a calculated mix of the main orbital parameters - eccentricity, obliquity (tilt) and climatic precession ${ }^{18}$. The 95 and $90 \%$ confidence intervals are shown for the $\delta^{13} \mathrm{C}$ spectrum. The $\delta^{13} \mathrm{C}$ spectrum displays power and is highly coherent (well above the 95\% confidence level) with ETP at the $405 \mathrm{kyr}$ frequency, despite our 2.4 Myrlong $\delta^{13} \mathrm{C}$ record only containing a maximum of six of these 'long' $405 \mathrm{kyr}$ eccentricity cycles. 


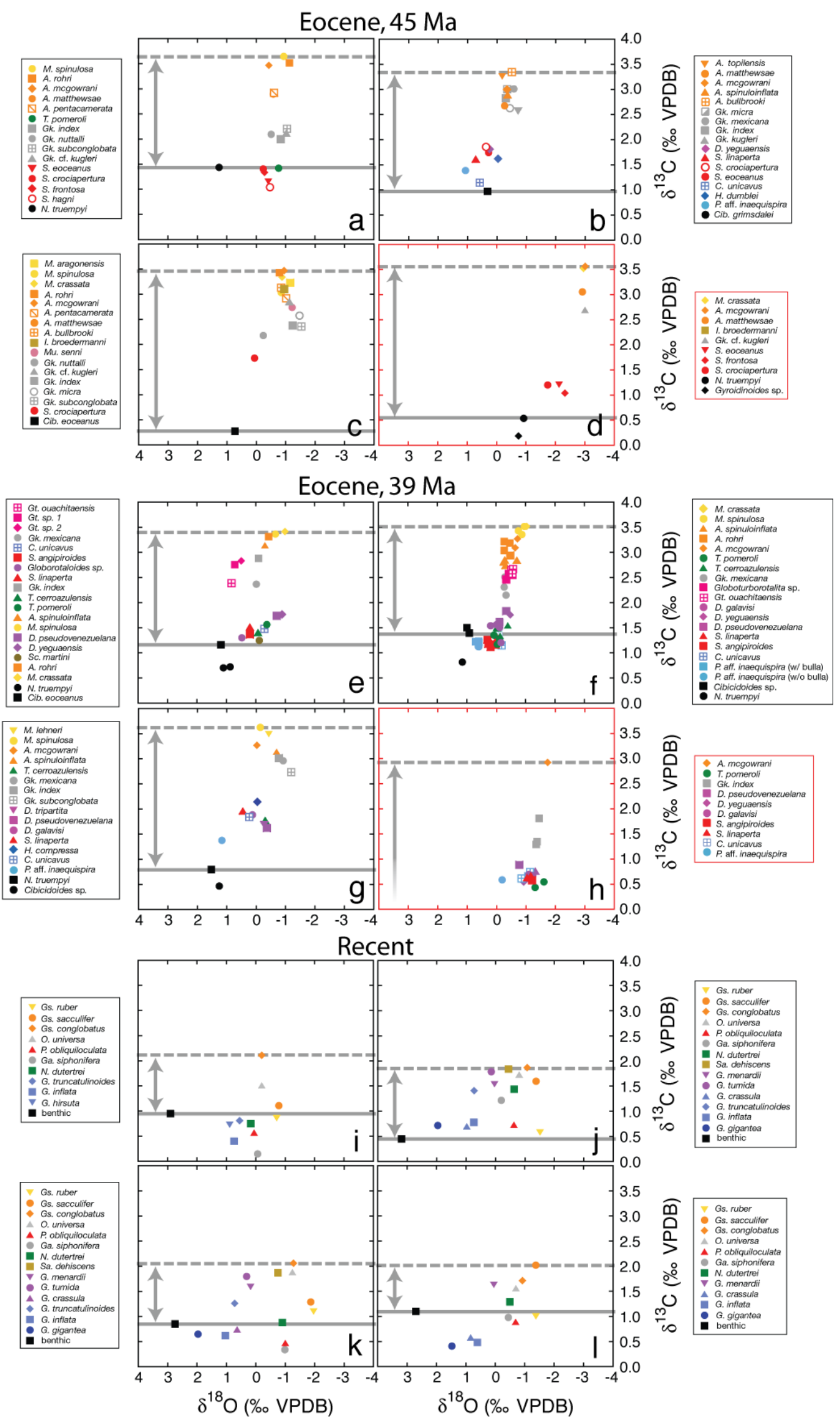


Supplementary Figure 4. Multi-species stable isotope arrays of the $\delta^{13} \mathrm{C}$ and $\delta^{18} \mathrm{O}$ of multiple species of planktic and benthic foraminifera from the early Middle Eocene (45 $\mathrm{Ma}$ ), the late middle Eocene (39 Ma) and from Recent core-top sediments. Horizontal grey lines indicate the highest $\delta^{13} \mathrm{C}$ of inferred mixed layer dwellers (dashed lines) and the lowest $\delta^{13} \mathrm{C}$ of benthics (solid lines). Benthic equilibrium $\delta^{13} \mathrm{C}$ and $\delta^{18} \mathrm{O}$ values for Recent samples calculated from modern seawater $\delta^{13} \mathrm{C}^{58}$ and temperature ${ }^{59}$ datasets owing to absence of data from foraminiferal calcite. Note that, in comparison to Recent data, Eocene data show i) a steeper vertical gradient of $\delta^{13} \mathrm{C}$ of DIC versus temperature and ii) a greater total surface-to-seafloor $\delta^{13} \mathrm{C}$ difference (grey vertical arrows). This larger Eocene surface-to-seafloor $\delta^{13} \mathrm{C}$ difference and steeper gradient of $\delta^{13} \mathrm{C}$ with depth is observed in typical 'frosty' (sensu ref. ${ }^{60}$ ) foraminifera (black plot frames) as well as 'glassy' ones (red plot frames), demonstrating that this larger Eocene vertical $\delta^{13} \mathrm{C}$ differential is not a diagenetic artefact. Furthermore, most Recent core-top planktic foraminifera are far from glassy, also typically having a somewhat frosty appearance. Planktic foraminifera with a lower $\delta^{13} \mathrm{C}$ value than co-occurring benthics likely indicate species with a strong 'vital effect' offset or a habitat in a pronounced oxygen minimum in the thermocline or intermediate waters. a, DSDP Site 94, Caribbean ${ }^{60}$. b, DSDP Site 523, S. Atlantic ${ }^{60}$. c, ODP Site 865, Eq. Pacific ${ }^{60}$. d, Tanzania Drilling Project (TDP) Site 2, Tanzania $^{60}$. e, ODP Site 1052B, NW. Atlantic ${ }^{61}$. f, ODP Site 1052F, NW. Atlantic ${ }^{60,61}$. g, ODP Site 865, Eq. Pacific ${ }^{60}$. h, Istra More 5 well, Adriatic Sea ${ }^{60,61}$. i, core OC28, NW. Atlantic $^{62}$. j, DSDP Site 361, SW. Indian ${ }^{63}$. k, DSDP Site 366, SW. Indian ${ }^{63}$. l, DSDP Site 389, SW. Indian ${ }^{63}$. Abbreviations for generic component of species binomials: i) Eocene, A. = Acarinina, Cib. $=$ Cibicidoides, C. = Catapsydrax, D. = Dentoglobigerina, $M .=$ Morozovelloides, Gk. = Globigerinatheka, Gt. $=$ Globoturborotalita, $H=$ Hantkenina, $I=$ Igorina, $M u=$ Muricoglobigerina, $N .=$ Nuttallides, $P .=$ Parasubbotina, Pa. $=$ Paragloborotalia, Ps. = Pseudohastigerina, $S .=$ Subbotina, Sc. $=$ Streptochilus, $T$. = Turborotalia. ii) Recent, Gs. = Globigerinoides, Ga. = Globigerinella, $G .=$ Globorotalia, $N .=$ Neogloboquadrina, $O .=$ Orbulina, $P .=$ Pulleniatina, $S a .=$ Sphaeroidinella. 
Supplementary Table 1. Stratigraphic positions of the Last Appearance Datum (LAD) of Discoaster lodoensis.

\begin{tabular}{lcccc} 
& Site & Core, section, interval $(\mathrm{cm})$ & \multicolumn{2}{c}{ Depth } \\
\cline { 2 - 5 } Top & 1210B & $16 \mathrm{H}-6,50$ & mbsf & rmcd \\
Base & 1210A & $17 \mathrm{H}-2,45$ & 150.20 & 168.83 \\
& & & 151.07 & 170.34 \\
Top & 1267A & $17 \mathrm{H}-2,30$ & mbsf & mcd \\
Base & 1267A & $17 \mathrm{H}-3,30$ & 153.2 & 170.01 \\
& & & 154.7 & 171.51 \\
Top & 1258A & & & \\
Base & 1258B & 5R-CC, 0 & mbsf & rmcd \\
\hline
\end{tabular}

Supplementary Table 2. Stratigraphic tie-points between Sites 1210 and 1258.

\begin{tabular}{ccccc}
$\begin{array}{c}\text { Site } 1210 \\
\text { rmcd }\end{array}$ & rmcd & $\begin{array}{c}\text { Site } 1258 \\
\text { adj. rmcd }\end{array}$ & age (Ma) \\
\hline 164.70 & tie to & 36.55 & 36.78 & 47.749 \\
164.97 & tie to & 36.82 & 36.99 & 47.777 \\
165.42 & tie to & 37.05 & 37.17 & 47.797 \\
165.63 & tie to & 37.30 & 37.36 & 47.818 \\
165.78 & tie to & 37.48 & 37.50 & 47.833 \\
165.96 & tie to & 37.72 & 37.72 & 47.853 \\
166.35 & tie to & 37.95 & 37.95 & 47.871 \\
166.74 & tie to & 38.62 & 38.62 & 47.915 \\
167.13 & tie to & 39.15 & 39.16 & 47.964 \\
167.46 & tie to & 39.38 & 39.39 & 47.989 \\
167.64 & tie to & 39.47 & 39.48 & 48.000 \\
167.70 & tie to & 39.93 & 39.93 & 48.023 \\
167.97 & tie to & 40.28 & 40.28 & 48.057 \\
168.07 & tie to & 40.42 & 40.42 & 48.075 \\
168.20 & tie to & 40.55 & 40.55 & 48.091 \\
168.36 & tie to & 40.64 & 40.64 & 48.102 \\
168.66 & tie to & 41.26 & 41.26 & 48.175 \\
168.78 & tie to & 41.66 & 41.66 & 48.220 \\
169.11 & tie to & 42.08 & 42.08 & 48.266 \\
169.41 & tie to & 42.28 & 42.28 & 48.290 \\
169.62 & tie to & 42.46 & 42.46 & 48.311 \\
169.77 & tie to & 42.65 & 42.65 & 48.339 \\
170.10 & tie to & 42.91 & 42.91 & 48.370 \\
170.82 & tie to & 43.46 & 43.37 & 48.417
\end{tabular}




\begin{tabular}{|c|c|c|c|c|}
\hline 171.33 & tie to & 43.02 & 43.68 & 48.456 \\
\hline 171.56 & tie to & 43.19 & 43.82 & 48.478 \\
\hline 171.81 & tie to & 43.54 & 44.10 & 48.519 \\
\hline 172.89 & tie to & 44.12 & 44.53 & 48.596 \\
\hline 173.61 & tie to & 44.44 & 44.78 & 48.661 \\
\hline 173.91 & tie to & 44.77 & 45.06 & 48.722 \\
\hline 174.21 & tie to & 45.17 & 45.39 & 48.777 \\
\hline 174.36 & tie to & 45.40 & 45.59 & 48.809 \\
\hline 174.63 & tie to & 46.08 & 46.15 & 48.897 \\
\hline 174.96 & tie to & 46.72 & 46.72 & 48.979 \\
\hline 175.26 & tie to & 47.29 & 47.29 & 49.058 \\
\hline 175.35 & tie to & 47.47 & 47.47 & 49.076 \\
\hline 175.50 & tie to & 47.72 & 47.72 & 49.110 \\
\hline 175.68 & tie to & 48.17 & 48.17 & 49.177 \\
\hline 175.98 & tie to & 48.35 & 48.35 & 49.206 \\
\hline 176.07 & tie to & 48.47 & 48.47 & 49.221 \\
\hline 176.43 & tie to & 48.73 & 48.73 & 49.246 \\
\hline 176.74 & tie to & 49.05 & 49.07 & 49.283 \\
\hline 177.00 & tie to & 49.35 & 49.35 & 49.327 \\
\hline 177.27 & tie to & 49.67 & 49.67 & 49.389 \\
\hline 177.57 & tie to & 50.40 & 50.40 & 49.465 \\
\hline 177.88 & tie to & 50.92 & 50.92 & 49.526 \\
\hline 177.99 & tie to & 51.05 & 51.05 & 49.544 \\
\hline 178.29 & tie to & 51.24 & 51.24 & 49.575 \\
\hline 178.49 & tie to & 51.35 & 51.34 & 49.599 \\
\hline 178.71 & tie to & 51.47 & 51.46 & 49.617 \\
\hline 178.95 & tie to & 51.93 & 51.93 & 49.701 \\
\hline 179.40 & tie to & 52.69 & 52.69 & 49.747 \\
\hline 179.67 & tie to & 53.48 & 53.48 & 49.801 \\
\hline 180.00 & tie to & 54.03 & 54.03 & 49.841 \\
\hline 180.54 & tie to & 55.08 & 55.08 & 49.914 \\
\hline 180.66 & tie to & 55.31 & 55.31 & 49.929 \\
\hline 180.87 & tie to & 55.53 & 55.53 & 49.943 \\
\hline 181.20 & tie to & 55.78 & 55.78 & 49.954 \\
\hline 181.44 & tie to & 56.16 & 56.16 & 49.970 \\
\hline 181.62 & tie to & 56.59 & 56.59 & 49.988 \\
\hline 181.83 & tie to & 57.17 & 57.17 & 50.013 \\
\hline 182.19 & tie to & 58.06 & 58.06 & 50.050 \\
\hline
\end{tabular}


Supplementary Table 3. Stratigraphic tie-points between Sites 1267 and 1258.

\begin{tabular}{|c|c|c|c|c|}
\hline \multirow{2}{*}{$\begin{array}{c}\text { Site } 1267 \\
\text { mcd }\end{array}$} & \multicolumn{4}{|c|}{ Site 1258} \\
\hline & & rmcd & adj. rmcd & age (Ma) \\
\hline 167.77 & tie to & 37.24 & 37.32 & 47.813 \\
\hline 168.20 & tie to & 37.95 & 37.95 & 47.871 \\
\hline 168.45 & tie to & 38.60 & 38.60 & 47.913 \\
\hline 169.01 & tie to & 39.15 & 39.16 & 47.964 \\
\hline 169.17 & tie to & 39.49 & 39.50 & 48.000 \\
\hline 169.35 & tie to & 39.98 & 39.98 & 48.027 \\
\hline 169.52 & tie to & 40.28 & 40.28 & 48.057 \\
\hline 169.65 & tie to & 40.59 & 40.59 & 48.095 \\
\hline 170.42 & tie to & 41.69 & 41.69 & 48.223 \\
\hline 170.60 & tie to & 42.07 & 42.07 & 48.264 \\
\hline 170.70 & tie to & 42.20 & 42.20 & 48.281 \\
\hline 170.85 & tie to & 42.30 & 42.30 & 48.293 \\
\hline 170.95 & tie to & 42.46 & 42.46 & 48.311 \\
\hline 171.12 & tie to & 42.54 & 42.54 & 48.321 \\
\hline 171.27 & tie to & 42.66 & 42.66 & 48.340 \\
\hline 171.41 & tie to & 42.75 & 42.75 & 48.356 \\
\hline 171.60 & tie to & 42.91 & 42.91 & 48.370 \\
\hline 171.75 & tie to & 43.18 & 43.18 & 48.393 \\
\hline 171.85 & tie to & 43.35 & 43.31 & 48.408 \\
\hline 171.97 & tie to & 43.64 & 43.52 & 48.436 \\
\hline 172.47 & tie to & 44.45 & 44.78 & 48.662 \\
\hline 173.28 & tie to & 45.20 & 45.41 & 48.780 \\
\hline 173.55 & tie to & 45.82 & 45.94 & 48.864 \\
\hline 173.71 & tie to & 46.74 & 46.74 & 48.982 \\
\hline 173.83 & tie to & 46.92 & 46.92 & 49.012 \\
\hline 174.30 & tie to & 48.24 & 48.24 & 49.193 \\
\hline 174.35 & tie to & 48.35 & 48.35 & 49.206 \\
\hline 174.65 & tie to & 48.55 & 48.55 & 49.229 \\
\hline 174.73 & tie to & 48.67 & 48.67 & 49.240 \\
\hline 174.81 & tie to & 48.72 & 48.72 & 49.246 \\
\hline 175.03 & tie to & 49.07 & 49.09 & 49.285 \\
\hline 175.37 & tie to & 49.68 & 49.68 & 49.390 \\
\hline 175.59 & tie to & 50.07 & 50.07 & 49.432 \\
\hline 175.81 & tie to & 50.37 & 50.37 & 49.463 \\
\hline 175.93 & tie to & 50.52 & 50.52 & 49.479 \\
\hline 175.95 & tie to & 50.60 & 50.60 & 49.487 \\
\hline 176.22 & tie to & 51.05 & 51.05 & 49.544 \\
\hline 176.40 & tie to & 51.47 & 51.46 & 49.616 \\
\hline 176.55 & tie to & 51.57 & 51.56 & 49.636 \\
\hline 176.85 & tie to & 51.94 & 51.94 & 49.701 \\
\hline 177.18 & tie to & 52.31 & 52.31 & 49.728 \\
\hline 177.55 & tie to & 52.78 & 52.78 & 49.752 \\
\hline 178.04 & tie to & 53.37 & 53.37 & 49.793 \\
\hline 178.45 & tie to & 54.02 & 54.02 & 49.840 \\
\hline
\end{tabular}




\begin{tabular}{lllll}
179.48 & tie to & 54.98 & 54.98 & 49.908 \\
179.67 & tie to & 55.22 & 55.22 & 49.923 \\
180.45 & tie to & 57.19 & 57.19 & 50.013 \\
180.82 & tie to & 58.06 & 58.06 & 50.050 \\
\hline
\end{tabular}




\section{Supplementary Note 1}

Data compilation in Figure 1a from refs $\mathrm{s}^{3,8,10,64,65}$.

\section{Supplementary Note 2}

References in Supplementary Information

48. Broecker, W.S. \& Peng, T.-H. Tracers in the Sea, (Eldigio, Palisades, 1982).

49. Broecker, W.S. \& Peng, T.-H. The role of $\mathrm{CaCO} 3$ compensation in the glacial to interglacial atmospheric CO2 change. Global Biogeochemical Cycles 1, 15-29 (1987).

50. Berger, W.H. Deep-sea carbonate and the deglaciation preservation spike in pteropods and foraminifera. Nature 269, 301-304 (1977).

51. Marchitto, T.M., Lynch-Stieglitz, J. \& Hemming, S.R. Deep Pacific CaCO3 compensation and glacial-interglacial atmospheric CO2. Earth and Planetary Science Letters 231, 317-336 (2005).

52. Tucholke, B.E., Vogt, P.R. \& al., e. Initial Reports of the Deep Sea Drilling Project, v. 43, (U.S. Government Printing Office, Washington, 1979).

53. Sibuet, J.-C., Ryan, W.B.F. \& al., e. Initial Reports of the Deep Sea Drilling Project, v. 47 Part 2, (U.S. Government Printing Office, Washington, 1979).

54. Whitmarsh, R.B., Beslier, M.-O., Wallace, P.J. \& al., e. Proc. ODP, Init. Repts., 173, (Ocean Drilling Program, College Station, TX, 1998).

55. McCave, I.N. Diagnosis of Turbidites at Sites 386 and 387 by Particle-Counter Size Analysis of the Silt $(2-40 \mu \mathrm{m})$ Fraction. in Initial Reports of the Deep Sea Drilling Project, v. 43 (eds. Tucholke, B.E., Vogt, P.R. \& al., e.) 395-405 (U.S. Government Printing Office, Washington, 1979).

56. Ghil, M. et al. Advanced spectral methods for climatic time series. Reviews of Geophysics 40(2002).

57. Paillard, D., Labeyrie, L. \& Yiou, P. Macintosh program performs time-series analysis. EOS, Transactions of the American Geophysical Union 77, 379 (1996).

58. Kroopnick, P.M. The distribution of d13C of CO2 in the world oceans. Deep-Sea Research Part A - Oceanographic Research Papers 32, 57-84 (1985).

59. WOCE Data Products Committee, World Ocean Circulation Experiment Global Data, version 3.0. in http://woce.nodc.noaa.gov/wdiu/ (Southampton, UK, 2002).

60. Sexton, P.F., Wilson, P.A. \& Pearson, P.N. Microstructural and geochemical perspectives on planktic foraminiferal preservation: "Glassy" versus "Frosty". Geochemistry Geophysics Geosystems 7, Q12P19 (2006).

61. Sexton, P.F., Wilson, P.A. \& Pearson, P.N. Palaeoecology of late middle Eocene planktic foraminifera and evolutionary implications. Marine Micropaleontology 60, 1-16 (2006). 
62. Erez, J. \& Honjo, S. Comparison of isotopic composition of planktonic foraminifera in plankton tows, sediment traps, and sediments. Palaeogeogr., Palaeoclimatol., Palaeoecol. 33, 129-156 (1981).

63. Shackleton, N.J. \& Vincent, E. Oxygen and carbon isotope studies in Recent foraminifera from the southwest Indian Ocean. Marine Micropaleontology 3, 218231 (1978).

64. Dutton, A., Lohmann, K.C. \& Leckie, R.M. Insights from the Paleogene tropical Pacific: Foraminiferal stable isotope and elemental results from Site 1209, Shatsky Rise. Paleoceanography 20, PA3004 (2005).

65. Norris, R.D., Klaus, A. \& Kroon, D. Mid-Eocene deep water, the Late Palaeocene Thermal Maximum and continental slope mass wasting during the CretaceousPalaeogene impact. in Western North Atlantic Palaeogene and Cretaceous Paleoceanography (eds. Kroon, D., Norris, R.D. \& Klaus, A.) 23-48 (Geol. Soc. of London, London, 2001). 